\title{
The English Language Usage of Teachers' Spoken Language in the Classroom Interaction
}

\author{
Ratmanida \\ English Department FBS UNP- Padang- Indonesia \\ ratmanida@gmail.com
}

\begin{abstract}
As it is the case in all the other professions, English teachers need to have competencies in English so called - English proficiency, a major content knowledge for EFL teachers. They should have, part of them is the knowledge of the language i.e. knowledge about English grammar or English usage in order to make teaching workable and realistic. The lack of English language proficiency in the interactional process in the classroom is assumed to be a stumbling block in the successful teaching. This paper aims at informing the result of a study on the English language Usage of Teachers' Spoken language in the Classroom Interaction. The site of the study is the Public Senior High Schools located in Padang that are implementing FISS programmes; and the participants are Physics teachers along with their students. Data of this study is drawn from direct classroom observation, questionnaire and intensive interview; and these data were analyzed quantitatively and qualitatively. The analysis of English language usage was focused on how the speakers, in this study the teachers of RSBI schools handled the basic rules of spoken language in the classroom; in particular, the use of words, such as nouns, verbs, adjectives, Adverbs, and Prepositions . It was found that The English language Usage of Teachers' Spoken language in the Classroom Interaction to some extent is still problematic
\end{abstract}

Keywords: Classroom interaction, language usage, spoken language, word and phrase construction

\section{INTRODUCTION}

In 2005 the Indonesian Ministry of National Education made a new policy on National Education system; that is the central government and local governments have to develop at least one school that has international standard, which is based on Law 20/2003 on national education system. In other word, each province and/or district has to establish one class or more fledgling international standard schools (FISS) known as Rintisan Sekolah Bertaraf Internasional (RSBI). The FISS is national schools which prepare and educate students based on both the Indonesian Education National Standard and International standards [1]. Today, these schools, however, has no longer existed. It has been declared by the constitutional court (MK) that the international-standard school pilot project (RSBI) was unconstitutional and they should be dissolved. This condition, in fact has long been predicted.

Since their establishment, these schools have been the subject of much public debate and controversy. For example, such a program has discriminated the poor from the rich as that a great number of students of those schools are from the rich family. Added to this, an output of FISS has not yet met the expected quality standard [2] since most teachers are still lack competence in English to make teaching workable and realistic [3, 4]. This is supported by the study carried out by Ratmanida that the occurrence of English in the teacher-student interaction was smaller than that of the occurence of Bahasa Indonesia [5]. For example, the use of English in Praises or Encourages (PE) appears 4 times $(0,8 \%)$ out of 562; Asking Question (AQ) appears 17 $(3,4 \%)$ out of 562; Accepts or Uses Ideas of Pupil (AUIP) 2 times $(0,4 \%)$ out of 562;. Giving Direction (GD) appears 17 times $(3,4 \%)$ out of 562 ; Criticizing or Justifying Authority (CJA) appears $0(0,0 \%)$ out of 562; and Explanation (E) appears 19 times $(3,8 \%)$ out of 562 . Overall the amount of English used by the teachers was only $11,8 \%$. The occurence of the English language used in the classroom interaction of the fledgling international standard schools does not meet the standard requirement of English for International standard schools, since the teaching and learning processes at an ideal International Senior High School are conceived as passing through the following stages;

Year 1 (one) $20 \%$ of school subjects are carried out bilingually;

- Year 2 (two) 50\% of the process of teaching and learning is carried out bilingually;

- Year 3 (three) $100 \%$ of the process of teaching and learning is bilingual; [1].

Given the fact on the standard requirement of Englsih, it may be assumed that the amount of English language use at these schools does not correspond with the standard requirement shown above. In otherwords, quantitatively, the English language use is not compatible with the standard requirement.

Beside the concern on the amount of English used by the teachers, their proficiency was aslso assumed to be the problem. Informal observation and evidence seem to support the claim that the lack of English language proficiency in the interactional process in the classroom is assumed to be a stumbling block in the successful implementation of the curriculum of these FISS.

As it is the case in all the other professions, The English teachers need to have competencies; a set of knowledge, skills, and behavior. They should have 
knowledge of the language [6], i.e. knowledge about English grammar or English usage, in which language usage in fact refers to the rules or structures used to form languages, while language use refers to the communicative meaning of language [7]. This difference is very similar to that proposed by Ferdinand de Saussure in his well-known distinction parole and langue. Saussure refers Parole to the actual way in which the language is used by practitioners, speakers and writers, and langue is the grammatical structure of the language as defined according to grammatical and syntactical categories [8].

The term "Language usage" that refers to grammatical structure of the language, is concerned with how sentences and utterances are formed; especially it deals with how the constituent units of sentence such as morphemes, words, phrases, and clauses are arranged to form sentences [9]. These elements underlie the linguistics features of this study, but it is limited only in looking at words of English constructed by the teachers

Words are not in the same type. Some of them are nouns, in which according to them, they denote classes and categories of things in the world, including persons, things, animal, abstract concept [10]. The other category of words are verbs. Verbs denotes actions, events, processes and states. They have three grammatical classes. One of them is Lexical verbs which denote types of action, state or event, and they are an open class in which new verbs are frequently created [10]. The next one is Auxiliary verbs, consisting of be, do and have. The final class is modal verbs, that are a closed class consisting of core modal verb (can, could, shall, will, would, must, may), semi modal verbs (dare, need, ought to, used to), and modal expressions (be able to, have to). In addition, verbs according to them also act as the head of verb phrases. The head is the first verb in the verb phrase, and it determines the form of what may follow

The following class of are adjectives. Adjectives describe properties, qualities or states attributed to a noun or pronoun [10]. They typically modified by adverb phrases, for example: He's a very tall man. An adjective phrase according to them can consist of single adjective or an adjective which is modified or complimented. Adverbs are a class of words which perform a wide range of functions. Adverbs are specially used to indicate time, manner, place, degree and frequency of an event, action or process. An adverb acting as the head of an adverb may be modified by another adverb.

A word is composed of one or more morphemes, and a morpheme itself is a smallest unit of meaning [10]. Some words consist of just one morpheme; some have even more morphemes. According to them, there are a number of types of morphemes. One of them is Affixes. Affixes are morphemes that are attached to the beginning or the end of words. Affixes attached to the beginning of words are called prefixes; those attached to the ends of words are called suffixes. The second type of morpheme is called inflectional morphemes. Some of the affixes express grammatical relations, for example the $-\mathrm{s}$ on $\operatorname{dog} s$ indicates plural; the past form drank contrast with the present drink. The third type is derivational morphemes. These derivational morphemes are the affixes that express lexical relations by forming new or different words when attached to basic words, for example: -able indicates that something is possible. These are derivational morphemes. The fourth type is Allomorphs. Allomorphs represent morphemes which vary in form, even though the meaning is similar. For example, im-penetrable, in-edible, ir-regular, all mean not. The fifth type is compounds, in which words combine with each other, for example: home and sick. These are all types of words structures.

The other view of grammar is related with the issue of acceptable and unacceptable forms. grammar is concerned with acceptable and unacceptable forms and the distinctions of meanings these forms create. This is because according to them in every language, some forms are acceptable and others are not either syntactically or morphologically [10]. "The issue of acceptability is never far from the surface when there is reference to what is standard in grammar or in language use in general" [10]. Therefore, to identify the correct or incorrect or acceptable or unacceptable form of grammar, the analysis of the language usage will be refered to usage manual of standard English Grammar

Therefore, the language usage elements provided by Carter and McCarthy above will be used as initial categories in analyzing the teachers' English language usage. The overall intention of the study is to investigate The English language Usage of Teachers' Spoken language in the Classroom Interaction . as shown in the following research question [10]. How is English used in the classroom interaction?

\section{METHOD}

The study aims to investigate; the use of English language usage in the classroom interaction; in particular, the use of word, such as nouns, verbs, adjectives, Adverbs, and Prepositions in the teachers' interaction in the classroom.

The research was carried out at SMAN I and SMAN $\mathrm{X}$ in Padang on grade 11. This study, in particular was carried out in one of the four subjects stated in "Permendiknas, no 78/2009, Mathematics and Science (Chemistry, Biology and Physics) which could use English or any other foreign language that commonly used internationally as medium of instruction. From the four subjects, the researcher randomly chose one of them, so called-Physics. The participants of this research were Physics teachers of the two schools along with their students.

The data of this study was drawn from a variety of sources: classroom observation, intensive interviews with teachers 
and students, and a questionnaire. Data was analyzed quantitatively and qualitatively

\section{FINDING AND DISCUSSION}

This section deals with the analysis on language usage of teachers' spoken language in the classroom interaction. The analysis is directed to answer the question "How is the English used in the classroom interaction?". The analysis of English language usage was focused on how the speakers, in this study, the teachers of RSBI schools handled the basic rules of spoken language in the classroom; in particular, the use of word, nouns, verbs, adjectives, Adverbs, and Prepositions in the teachers' interaction in the classroom.

\section{A. The Use of Words}

This section concerns the accuracy of use of words by the RSBI teachers. The discussion focuses on the use of nouns (e.g., velocity, gas, book, direction, and statement), verbs (e.g., do, write, tell, move, got, do , is and are), adjectives (e.g., ideal, same, free and small), adverbs (safely and freely), and prepositions (e.g., for, about and in). These words were found constructed in various ways.

\section{B.The use of Nouns}

The use of English nouns by the teachers appears to be accurate. There is no problem found in the formation of the English nouns by the teachers. This can be identified from the use of nouns in the form of base and derivations through suffixation, as exemplified below

\section{$\underline{\text { Base }}$}

Book as in Please write in your book

Gas as in Tell for me what is the ideal gas?

Velocity as in This is not all the same velocity

\section{Suffixation}

direction (root: direct) as in How the direction?

statement (root: state) as in What statement Charles Gaylusac about gas?

The words book, gas and velocity are all base forms in English as can be seen from Oxford English dictionary. In addition, the word direction is a corrrect formation of English noun. The noun is derived from the root direct through the process of suffixation. The suffix ion is attached to the verb direct to form a noun. This similarly happens to the noun statement. The word statement is a corrrect formation of English noun. The noun is derived from the root state through the process of suffixation. The suffix -ment is attached to the verb state to form a noun. It could be said that the formation of English nouns by the teachers are accurate. As the suffixes added to verbs are relevant for constructing noun [10].
Therefore, the teachers are able to use noun in the form of base and derivations through suffixation (e.g., -ment, ion). There are 35 nouns that have been used correctly and none is used incorrectly. 23 nouns are in the form of base and 12 nouns are in the form of derivation through suffixation. The limited number of English noun that occured is due to the limited amount of English used by the teacher in the classroom which is much more smaller than the amount of bahasa Indonesia (see chart 4.3).

\section{The use of Verbs}

There are two cases of verbs that will be discussed in this section, i.e. the use of lexical verbs and auxiliary verbs. The use of lexical English verbs by the teachers was generally accurate. There is no problem found in the formation of lexical English verbs by the teachers. This can be detected from the use of verbs, either in the form of base or inflection, as exemplified below

$\underline{\text { Base }}$

Write as in Please write in your book

Tell as in Tell for me, what is the ideal gas

Move as in Move free

\section{Inflection}

got (root: get) as in After we got about gas we continue about zzzz ideal gas

The words write, tell, and move are all lexical verbs which according to Carter and McCarthy (2006) indicate types of action, state or event. They are all base forms in English. The use of these base forms was generally accurate because they are used in imperative. In addition, the word got is a correct form of English verb. The verb is derived from the root get through the process of inflection that is through internal vowel change. The vowel $e$ is changed to $o$ as in got to form a past tense of get. It could be said the teachers are able to use lexical verb in the form of base and inflection (e.g., get-got).

Yet, the use of auxiliary verbs by the teachers is not always accurate. This can be detected from the use of auxiliary verb as exemplified below

$\begin{array}{llll}\text { Are } & \text { as } & \text { in } & \text { *Are you understand? } \\ \text { Is } & \text { as } & \text { in } & \text { *How the interaction? }\end{array}$

The auxiliary are as in Are you understand? is used incorrectly. The correct auxiliary for this question should be $d o$, since the verb is not in progressive form. In addition, the auxilairy verb "is" must appear in the question "How the interaction?"; and it should be placed before the subject "the interaction". Thus, the correct use of the auxiliary verb in the following question should be What is the interaction?. Therefore, it could be said that the teacher still lacks of using the auxiliary verb.

However, the other auxialiry verbs are accurately used as exemplified below

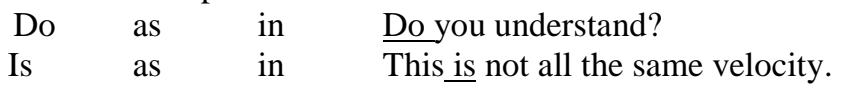


The auxiliary verbs $d o$ and is above have been used correctly. They agree with subjects, i.e.you and this.

Based on the data, the number of correct use of verb is much higher than that of incorrect uses. There are 41 verbs consisting of lexical and auxialiary verbs have been used correctly; and two auxialry verbs have been detected to be incorrectly used. The incorrect use of auxiliary verb (e.g., "is") is made by the similar teacher and it occurs several times. It consequently indicates that the teacher generally knows the use of verbs but she does not use them accurately and consistently. In other words, the teacher generally knows the use of verb, but she may lack of English usage competence in particular, in using auxiliary verbs.

\section{The use of Adjectives}

The use of English adjectives by the teachers was generally accurate. There is no problem found in the formation of the English adjectives by the teachers. This can be identified from the use of adjectives in the form of base and derivations through suffixation, as exemplified below

$\underline{\text { Base }}$

Same as in This is not all the same velocity.

Small as in Interaction course in atom is small

\section{$\underline{\text { Suffixation }}$}

Ideal (root: idea) as in Tell for me, what is the ideal gas

The words same and small are all base forms in English as can be seen from Oxford English dictionary. In addition, the word ideal is a correct formation of English adjective. The adjective is derived from the root idea through the process of suffixation. The suffix $-a l$ is attached to the noun idea to form an adjective. It could be said that the formations of English adjectives by the teachers are accurate. A suffix $-a l$ be added to a noun is relevant for constructing adjective [10]. Based on the data, there are 6 adjectives that have been used correctly and none is used incorrectly. It consequently indicates that the teachers are competent in using adjectives in the form of base and derivation through suffixation (e.g., $-a l$ ).

\section{E. The use of Adverbs}

The use of English adverbs by the teachers is not always accurate. There is a problem identified in the use of adverb, as exemplified below
Free as
in
*Move free

The word free is incorrectly used as shown in the sentence move free. The verb move is modified by the adjective free. The correct construction actually should be with an adverb freely. It modifies the verb move. Therefore, the use of adverb by the teachers is still problematic. It may be caused by direct translation of the teachers' first language bergerak bebas into target language (English) move free.
However, the use of adverb by the teacher is sometime accurate as shown below

Safely as in We safely live in the gas

The word safely is a correct formation of English adverb. The adverb is derived from the root safe through the process of suffixation. The suffix $-l y$ is attached to the adjective safe to form an adverb. It could be said that the formation of English adverb by the teachers is accurate. A suffix $-l y$ added to an adjective is relevant for constructing adverb [10].

The two examples above are used by the similar teacher. Therefore, it could be said that the teacher in fact knows how to use adverb, in particular attacking -ly to an adjective to form an adverb but she is inaccurately and inconsistently in using it.

\section{F. The Use of Prepositions}

The use of prepositions by the teachers is not always accurate. There are problems found in the use of the prepositions. This can be detected from the use of prepositions, as exemplified below

About as in * we continue about zzzzz ideal gas

For as in *Tell for me what is the ideal gas

The preposition for and about are used incorrectly as shown in the sentences Tell for me what is the ideal gas and in we continue about zzzzz ideal gas". The preposition for in the sentence Tell for me what is the ideal gas should be omitted. The correct formation will be Tell me what the ideal gas is. This similarly happens to the prepostion about. The preposition about in we continue about zzzzz ideal gas should be changed to preposition on, the correct use of the preposition in this sentence will be we continue on $z z z z z$ ideal gas. In other words, the uses of prepositions by the teachers are still problematic.

However, the use of preposition by the teacher is sometime accurate, as exemplified below

In as in Please write in your book

of as in Gas consists of?

As shown above, the preposition in and of are used accurately in the sentence please write in your book and in Gas consists of ?. This consequently indicates that the teachers generally know how to use preposition (e.g., preposition in and of) but she still has slight problems in using it. This is because data on the use of preposition by the teachers show that 13 prepositions have been used correctly while the other two prepositions have been used incorrectly; in particular the use of preposition for. It seems the teacher is not familiar with the use of preposition for. This is because she uses the similar case at the other context, for example Who is can tell for me what is the ideal gas? ; and she seems to be aware of using it. It could be said that the teacher has a problem in using preposition for. In addition, although it has been detected that the use of preposition about is inaccurate, the similar teacher has been found to use the preposition about accurately at the 
other context as in What Boyle Statement about gas?. This consequently indicates that she knows how to use it, but she is inaccurate in using it. Therefore, it could be said that in general the teachers know how to use the prepostions, but they still have slight problems in using it.

Based on the the description of English language use above, it is obvious that English has slightly been used in the classroom interaction at the Fledgling International Standard Schools (FISS). The analysis of the spoken English language usage made by the teachers above found that although there are some correct or acceptable English language usage made by the teachers such as the use of nouns, verbs, adjective, there are in fact some problems occurred especially in verbs, adverbs, and prepositions . The findings indicate that the English language usage of FISS teachers of the research sites are still problematic.

This finding is confirmed by the students' claim in the interview that the teacher has grammatical problems in her spoken English. This is evidenced in the following interview excerpt.

Kadang guru tidak bisa Bahasa Inggris, susah ngerti, grammar bolak balik, jadi kita kita susah memahaminya .....

"some time the teacher is not able to communicate in English. It is difficult for us to understand her lesson, one of reasons is due to her English grammatical problems" (\#3, a student of site B).

The above students' claim corresponds with the students' reaction in the questionnaire that $66,67 \%$ of the students were disagree with following statement in the questionnaire saya dapat memahami penjelasan guru dalam mengajar Fisika karena bahasanya jelas meaning I can understand the teacher's explanation because of the teacher's intelligible English language" . In other words, the students in general have problem with the teacher's English language. Therefore, by triangulating the data, it is obvious that the teachers in general have problems with her English, in particular, with her English language usage.

\section{CONCLUSION AND RECOMMENDATION}

The research question concerns the use of English in the classroom interaction. The analysis of the use of the spoken English language by the teachers in general shows some correct or acceptable English language usage, for example in the use of words (e.g., nouns, verbs, adjective). However, some problems in usage occured especially in the use of verbs, adverbs, and prepositions. It may be concluded that that the English language usage of FISS teachers of the research sites is still problematic . The target of FISS, that is efective learning using English in addition to Indonesian has not yet been achieved. This is principally because the teachers' English competence is inadequate, though English is the key element in the FISS program. It would then be concluded that these schools are not yet ready to carry out the FISS program satisfactorily.
Based on this finding, it is suggested that the teachers of fledgling international standard schools who teach Physics subject should ensure that they are competent in English in order to reduce problems or difficulties for students arising from incorrect usage. At the same time, while teachers are working to improve their English, the schools also need to ensure that students have high standard of English comprehension. Following on from this, the teachers should not force themselves to use English in explaining conceptual contents. They should use English systematically and gradually as their competence increase (Suherdi, 2012). This is because teachers need to give clear comprehensive explanations of the subject matter to the students, and make sure that all students understand the conceptual content presented [11].

It is suggested that Teacher Training Institutions make sure that their students who are going to be teachers of fledgling international standard schools are competent in English, or minimally that their English is intelligible. Iit is also suggested that the English department of Teacher Training Institutions work collaboratively with the Physics Educational department to design a program to train students to be FISS teachers and to upgrade the existing FISS teachers. The English skills should be taught to students by those who work at English language departments and who have a professional concern in relationt students' qualifications in English, and can administer exit level tests which should be carried out in several intervals [11]. It is also suggested that they need to revisit the requirements for candidate teachers of FISS locally and nationally. Certificates gained from Teacher Training Institution program proposed above could then, as just suggested, be one of the requirements

\section{References}

[1] Depdiknas. Panduan penyelenggaraan rintisan SMA bertaraf internasional. Jakarta: Author. 2007

[2]Suparto. Kebijakan semu, RSBI perlu diberhentikan. Retrieved March 24, 2011, from http://metrotvnews.com/read/news/2011/03/24/46365/ke bijakan-semu-RSBI-Perlu-Diberhentikan. 2011

[3] Hidayat, M., \& Masita, E. The bilingual education as SMP 1 Jambi: Teachers problems. 2005

[4] Suraya, L. The practice of english foreign language teaching at international class at SMU Kotamadya Padang. The 53rd TEFLIN. Yogyakarta. 2005

[5] Ratmanida The Dynamics of Classroom Interactions: A Case Study at Fledgling International Standard Schools in Padang, West Sumatra. Unpublished Dissertation. 2012

[6] Borjars, Kresti and Burridge, Kate. Introducing English Grammar (Second Edition). Hodder Education, an Hachette UK Company. London. 2010

[7] The British Council. Teaching English. Available: http://www.teachingenglish.org.uk/knowledgedatabase/language usage Accessed 26 September 2012 
[8] Saussure, Ferdinand de. Course in General Linguistics. Eds. Charles Bally and Albert Sechehaye. Trans. Roy Harris. La Salle, Illinois: Open Court. 1983

[9] McCarthy, M. Discourse analysis for language teachers. Cambridge: Cambridge University Press. 1990

[10] Carter, Ronald and McCarthty, Michael. Cambridge Grammar of English: A Comphrehensive Guide Spoken and Written English Grammar and Usage. Cambridge: Cambridge University Press. 2006

[11] Suherdi, D. Selayang Pandang MPDELS (Model Pembelajaran Dwi Bahasa Empat Lapis Sinergetik). Celtics Press. Bandung. 2012 